\title{
Inclusive Education: The Performance of Teachers with Disabled Students
}

\author{
Dayana Tainá A. Silva, Erika Rodrigues de Freitas, Otília Maria A. N. A. Dantas \\ University of Brasília - UnB \\ Brazil
}

\begin{abstract}
The research aims to analyze teaching practices in inclusive education from the perspective of public schools of the Federal District of Brazil, understanding the development of teachers that work with special educational need students. The object in question is structured from the following problem: What is the perception of teachers regarding students with disability? For the methodology we opted for a research of qualitative nature, under bibliographical, documental, and field research. The research tools used were questionnaire and observation with teachers. The study is based on the following authors: Carvalho [3], Cervo, Berviam and Silva [4], Coelho [5], and Silva [1], that contextualized child development and inclusive education. We sought to investigate the opinion of teachers today in the inclusive teaching as a way to sensitize them to a transforming practice in the student training. The results of the research show that teachers are aware of inclusive education; however, they show lack of knowledge around different disabilities and adopting resources and differentiated activities in the classroom with students that show some limitation. We conclude that continuing education is a way to overcome and progress in pedagogical practices in the school context because teachers can not only search for ways of teaching, but also to learn on their day to day practice, which would bring a more meaningful look from the teacher towards the students.
\end{abstract}

\section{Introduction}

The current research titled "Inclusive education: the performance of teachers with disabled students", have as problem statement: What is the perception of teachers regarding students with disability? Starting from the basic concepts of learning, teacher training, and intellectual impairment, the study outlined as a general objective to analyze ways of teaching during internships on public schools of the Federal District of Brazil (DF) under the inclusive education perspective. Hereupon, the specific objectives are to: draw the conception of inclusive education and its main deficiencies; understand how teaching practice works with disabled students, as the importance of continuing education in this process.

The justification emerged from the theme choice, that was suggested based on the story of one of the authors of the paper that has intellectual impairment, and the need to understand how teachers deal with disabled students on public schools of DF.

We consider important that in the education field teachers value stages of human development because they are related to learning. But to be able to explain this concept there are some theorists that help us understand it from a broad perspective, such as understanding how the relationship between subject and learning works [11]. Some of the theories used in this study are conception of Piaget and Vygotsky. From the theoretical reference and field research, we observed that the conclusion of this paper brings continuing education as a way of overcoming and advancing pedagogical practices in school, since teachers can search not only ways of teaching, but also learn on their day to day practice which makes observing students more meaningful. Accordingly, it is necessary that the teacher always seek continuing education, an improvement to understand student limitations and find in the pedagogical practice methods, means, solutions, and ways to bring to those students a meaningful learning. It is believed that this theme can contribute to the inclusion of disabled students in school, as a way to make teachers look at that subject, and to the transformation of ways of thinking and acting when you understand that everybody should be treated equally.

\section{Methodology}

The research was qualitative and quantitative. In a qualitative matter, it's a research that goes beyond data gathering, since it's an interpretative research and it can change at any moment, having a complex, multifaceted, and interactive reasoning, with varied research strategies [6].

This study happened upon bibliographical and field research. To Gil [8] (p.44), "the bibliographical research is developed based on in-depth material, done mainly on research and scientific papers". Gil [8] stresses that it is necessary to materialize 
inclusive education in the teaching and learning process following the footsteps of renowned authors.

Parra and Almeida [9] (p.102), describe that field research " $[\ldots]$ is the research under questionnaire or interview under the involved elements, and that allows analysis and conclusion, under the previously established goals. [...] This research bases on observing facts as they happen." The field research was done with teachers of elementary schools of the Education Department of the Federal District of Brazil. The research had the objective of analyze and understand the performance of those teachers with special need students.

The data collection was done through questionnaire with closed and open questions. Cervo, Bervian, and Silva [4] (p. 53) say that "[...] the questionnaire is the most used form of data collection, because allows us to measure what we want with more precision. In general, the word questionnaire refers to a way to obtain answers to questions under a formula selected by the person that answers the questionnaire." The questionnaire was chosen to be a part of this study because it offers the possibility to reach the goals set in the beginning of this paper.

\section{The development of learning in inclusive education}

To be able to talk about inclusion, firstly it's necessary to understand how development of learning in the inclusive education is conceived. To Coelho [5] (p.13): "It is considered that learning comes from the relationship established between subject and environment.". In the classroom, the teacher establishes a bond with the student through conversation, allowing a better adaptation to the environment, as well as an understanding of what's being studied.

The knowledge establishes from the joint action between subject and environment. Therefore, it is believed that it is of utmost importance that within the scope of inclusive education a differentiated look from the teacher towards the students that are or seem to be disabled or any other kind of limitations that would prevent them to acquire knowledge like the "normal" students. The assimilation and accommodation presented by Piaget show how a process of knowledge adaptation, in which the student has already owned the knowledge to seek the balance needed to structure the ascending lines from the simplest to the most complex knowledge.

The approach to development ends with Vygotsky's theory that created the Proximal Development Zone concept. To Coelho [5] (p.45) "[...] the cultural and historical environment are defining the human development, that allows to overcome the dualities man/social, natural/culture, biological/social, reason/emotion."
To Vygotsky, the environment influences the student's learning development in a way that the Immanent Development Zone allows the symbolic mediation between the Real Development Zone. In the inclusive education this approach is conceived by schools as a theory of utmost relevance, since there is a perspective of overcoming barriers in the difficulties that the student has. In turn, the professor can find in this approach a foundation to the pedagogical practices in interactions with the students.

\section{Types of disability: a brief explanation}

To Carvalho [3] (p.15), "the special education has been considered as the education of people with disabilities, either mental, hearing, visual, motor, physical, multiple, or due to invasive development disorders." That said, we highlight that people can show limitations, for example, due to some disabilities.

Physical, hearing, mental, and visual disabilities require a change in behavior from teachers and professors. And because of that, a decree was created, Federal Decree no. 3,298, December 20th 1999, in which hearing disabilities are defined as "bilateral, partial, or total loss, of forty one or more decibels $(\mathrm{dB})$ measured by audiograms with frequencies of $500 \mathrm{~Hz}, 1,000 \mathrm{~Hz}, 2,000 \mathrm{~Hz}$, and $3,000 \mathrm{~Hz} "[2]$.

Hearing Disability is one of the most studied disabilities in the academic field; however, it is noted that it still needs to be researched and worked on in order for it to be enhanced in activities from the educational and social field of the subject. It is noted that " $96 \%$ of deaf children with have hearing parents, and the educational institution it is represented as a privileged environment for acquiring the first language. This way the education of the deaf child will happen in a way that promotes their development, considering the important role of the language" [7] (p.24).

If most of the people with hearing disabilities are the child of hearing parents, it is required a more intensified social work from the school, university, and government, so there is an organization to the planning phase. The inclusive education can happen actively during teaching, and during student and parents' life, but for that it is required a commitment from the society and from the subject themselves.

After talking about hearing disability, we will talk about Visual Impairment that refers to: total loss of eyesight - known as blindness - or a situation where there's low vision. Therefore, it can be defined as:

- Blindness: situation where there's total loss of eyesight, including also total loss of light projection. The blind student will need for their education development specific services, such as: 
domain Braille, soroban, orientation and mobility, among others.

- Low vision: damage in the visual function even after treatment and/or optical refraction. The conditions of low vision vary, such as the special education needs of the student with low vision, that can change from one student to another depending on the level of their visual loss. [7] (p.25).

In the visual impairment usually there's a more accurate diagnosis to ascertain the student behavior. In the Department of Education there is a school specialized in teaching those students, called "Centro de Ensino Especial de Deficientes Visuais (CEEDV)", taking into consideration that other schools are not ready to teach students with this disability.

Physical Disability can be defined as "When there the motor skills are affected in a way that impacts the mobility, motor coordination in general, and/or speech. Usually those implications are due to neurological, neuromuscular, orthopedic, rheumatic injuries or congenital malformation. Thus, as defined in national guiding documents (MEC, 2004), physical disability is the impairment of the locomotor system, that includes the osteoarticular, muscular, and nervous system". [7] (p.27).

Mental Disability, more precisely intellectual disability, we understand it that to be able to talk about it, it is necessary to know its terminology. In this context, Belo, Caridade, et.al. [1] (p.4) say that intellectual impairment is "In the first half of the twentieth century the Intelligence Quotient (IQ) was known as an estimate of the innate intelligence potential, a reflex of a general, unidimensional, and undetermined intelligence that is unalterable and not permeable to the sociocultural and educational influences. In parallel, intellectual disability was envisaged as an intellectual deficit, in which IQ was its numerical expression, of an individual and organic etiology nature, immutable and incurable".

IQ with deficit was considered a factor to determine intellectual impairment even knowing that there were other variables to the diagnosis. In this sense, the child that showed low IQ was considered intellectually disabled, but this low IQ could be due to several different things, including birth complications. Over the years, parents started noticing that it wasn't just IQ, but also different difficulties in learning, in behavior, and even in social life. However, those weren't investigated early in life, and when they got to school, the difficulties started, and most of the time were noticed by the teachers that would send the students to get support (therapists, educators, psychopedagogist).

Still in this subject it is important to highlight the most recent definition of Intellectual/Mental Disability "The American Association on Intellectual and Developmental Disabilities - AAIDD defines intellectual/mental disability as "disability characterized by important limitations, both intellectual functioning and adaptative behavior, expressed in conceptual, social, and practical adaptive skills. This inability starts before 18 years old" [7] (p.22).

This way, some difficulties shown by people that have low IQ are highlighted: difficulty to solve problems not only mathematical, but also related to the everyday life; difficulty to debate and answer to group, family, school situations; difficulty to process information; difficulty to read and write; it can show other disorders such as ADHD (Attention Deficit Hyperactivity Disorder), dyslexia, among others [10].

The person with intellectual disability shows difficulty in the social and school environment, however, develop skills from learning motivating practices either by music, games, reading, painting, among others that can express their development capacity to learn and teach. Therefore, it is believed that "Intellectual abilities refer to intelligence, known as a general mental ability, whose application happens by reasoning, planning, problem solving, abstract thinking, comprehension of complex ideas, and fast learning based on their own experience. Adaptative behavior is the union of conceptual, social, and practical skills that were learned through people and practiced in the everyday life" [7] (p. 23).

In this study we talked about the concept of a few disabilities and its limitations. This way is important that the student is accompanied by a support team to be able to develop those skill in school and in college, since it will also support the learning process and inclusion of those students helping them overcame barriers not only to win, but also to transform the knowledge into citizenship.

\section{Inclusive education under from the perspective of teachers of the Department of Education of the Federal District (SEEDF)}

According to the proposed goals we thought about the importance of verifying what is the perception of teachers from the SEEDF about inclusive education and understand a bit better the inclusion process. For that we asked six teachers (P1, $\mathrm{P} 2, \mathrm{P} 3, \mathrm{P} 4, \mathrm{P} 5$, and P6) from different areas within the Department of Education mentioned above to answer a questionnaire with ten open questions.

\section{A differentiated work: the adaptation of public school to students with special needs}

Initially, regarding the organization of the physical and pedagogical structure of the public 
school to receive students with special needs, the participants of

this research let us know that for the students that are not included in the regular classes there are special classes where "everything is prepared to welcome the special student (...) and we also make curricular adaptations and adjustments" (P1). "The pedagogical team tries to adapt the spaces in the school, but those changes need support from the government" (P2). "The schools, by law, must be adapted to welcome students with various disabilities" (P4).

We notice from the answers from the teachers that the school tries to adapt the pedagogical content and the physical space to welcome those students, but not always this is possible, because financial support from the State is needed, even having existing laws that support the students with special needs. We mentioned the demands related to the specialists to be able to support those students, but "the school must have a team of specialists that fulfils the demands from the special student within the reason" (P6).

\section{The role of the teacher in inclusive education}

We believe that the role developed by the teacher in the classroom is of fundamental importance for the inclusion of special students and in the improvement of learning, given that it is needed to have a differentiated look at those students. In this context, we asked the teachers what the role of the teacher is related to those students with disability or disorder and how can the teacher help in the development of their activities. The answers are listed in Table 1.

Table 1. The role of the teacher in inclusive education

\begin{tabular}{l|c}
\multicolumn{1}{c}{ Answers } & Frequency \\
\hline Have a differentiated look & 01 \\
$\begin{array}{l}\text { Create resources to attain the } \\
\text { student needs }\end{array}$ & 01 \\
$\begin{array}{l}\text { Propose activities to integrate the } \\
\text { class }\end{array}$ & 03 \\
Be the learning facilitator & 02 \\
Respect the student limitation & 02 \\
Work on respect and differences in & 01 \\
class & 10 \\
Total Source. Table created by the authors.
\end{tabular}

About the role of the teacher we observe that the ones researched above mentioned having a differentiated look to the students besides promoting integrating the class. We understand that respecting the differences and having the adequate activities are factors treated as essential to support the student learning.
According to the teachers, the development and didactic planning of the activities for the special students happen on an individual basis, because "in school we don't always have the needed resources" (P1). The teachers are notified about the diagnosis of each special student to be able to plan the activities.

Other documents from the SEEDF are utilized, such as the Currículo em Movimento da SEEDF, "with the right adjustments and adaptations to each class" (P3), showing that some teachers have the knowledge of official documents and use it to write their pedagogical plan.

\section{The pedagogical support of specialty teams}

In the SEEDF there are support teams to the teachers regarding students with disabilities (Sala de Recursos) and to the students with functional disorders and difficulty learning (Equipe Especializada de Apoio à Aprendizagem). According to the documents from SEEDF, such as Orientações Pedagógicas (Pedagogical Orientation) of those services, those teamwork with the intervention and assistance to the teachers in regard to the learning process of those students and adequation of the content to the plan of activities.

In the theme of inclusion, we questioned how the articulation between the Equipe Especializada de Apoio à Aprendizagem (Specialized Learning Support Team), Sala de Recursos (Resources Room), educational orientation, pedagogical coordinator, and others, regarding the work developing children with special needs happens.

Table 2. Articulation between the support team, coordinator, and others

\begin{tabular}{l|c}
\multicolumn{1}{c|}{ Answers } & Frequency \\
\hline There's no articulation & 02 \\
There are meetings between & 02 \\
teachers and the teams & 01 \\
Rarely this articulation occurs & 01 \\
There's a fragmentation in the & \\
pedagogical work in school & 01 \\
Periodical meetings with the student & 01 \\
family & $\mathbf{0 8}$ \\
School projects & \\
Total Source. Table created by the authors.
\end{tabular}

We notice that the articulation is not visualized by everyone in school. "The resources room wasn't even working this year" (P1). The lack of professionals still shows as a big problem in public schools of the Federal District and it was possible to notice that the teachers would like that there was more integration in the whole school towards the students with special needs because the fragmented work still persists. "It is observed a fragmentation 
due to a great demand of work that each of us get, leaving a big gap on following up on the development of those students" (P4). Pedagogical projects were mentioned as school articulation, given that "the school promotes reflexive inclusive actions between teachers and students (...) through projects" (P6).

\section{Inclusion and continuing education: influences in the teaching work?}

We understand that continuing education is the facilitator of the praxis teaching method, and regarding the practice of the teacher in inclusion cannot be different. This way, we questioned the participants if the teacher training is important to be able to work with special children.

Table 3. Teacher training and its possible influences

\begin{tabular}{l|c}
\multicolumn{1}{c}{ Answers } & Frequency \\
\hline $\begin{array}{l}\text { It's important to know the } \\
\text { characteristics of each disability } \\
\text { Understand what are the obstacles }\end{array}$ & 01 \\
in learning & 01 \\
$\begin{array}{l}\text { Dominate the correct techniques } \\
\text { and strategies }\end{array}$ & 04 \\
It's important that teacher take & 01 \\
courses in the EAPE & 01 \\
Update your practice & 02 \\
Acquire theoretical basis & 01 \\
Have a new look towards training & 10 \\
Total &
\end{tabular}

Source. Table created by the authors.

Knowing the methods and techniques to work with special children was mentioned by $50 \%$ of the participants of the research. It is observed that the teachers are in search of strategies and have a lot of questions about how child with disability or disorder. "No doubt, the continuing education helps the teacher improve their practices, ways of teaching, and rethink on your performances a lot" (P2). The relationship between theory and practice is a part of conscience of those teachers: "joining theory and practice are skills developed mainly in the continuing education" (P4).

We understand that the teachers have continuing education as foundation to their practice and consider theoretical study as one of the success factors; also understand that not only theory is important, but also how they will conduct learning on those students under the reality of inclusive education. "With continuing education, the teacher understands better the characteristics of student development and how to contribute to a satisfactory process of learning" (P4). "Firstly, the teachers need to want to do a different job to be able to meet the demands of the student; also, it's important to know this student and his specificities and study their disability" (P6).

\section{Summary and conclusion}

The focus of this article was to analyze the teaching practices in the inclusive education from the perspective of public schools of the Federal District. With the referential used and the field research it was noticeable that the theme of inclusive education was present in the current reality of school, and the teachers and professionals involved in the pedagogical organization of the school need to have an even more sensitive look towards that every time. When analyzing the data, it was noticed in the field that knowledge towards kinds of disability and disorders is very valuable to education professionals. From the knowledge of specific disabilities, the teacher can trace a work plan that will fulfil the needs of each student.

Inside this public primary school, it was possible to observe that currently there are improvements, especially in the growth of special students in the inclusive classes, lowering the consultation in the specific center of special teaching.

The school seeks to adapt its structure to welcome students, however we verify that that's not always possible. Even so, the teachers seem engaged in this adaptation, not only physical but also adaptation and adequacy to the curricular components. Thereunto, it was verified that there are support in the school, such as, the teachers in the Resources Room and the Learning Support Team.

We also understand that with this study it's up to the school to search for alternatives to contemplate the learning of students with disabilities and related disorders, making with each shared learning with the students to be meaningful to them; in other words, the school will need to make adaptation and adequation to the activities in a way to teach people with disabilities, in order that there's nothing lacking labeling that those people need differentiated support.

With the school, it's viable to the teachers to search diverse alternatives to work with students that demands specialized support because those students have the right to have guaranteed access to a meaningful and quality education. The use of curricular adjustments, mentioned earlier, must then happen through meetings with the faculty of the educational institution where the student studies and family participation are of fundamental importance to the growth of people in general.

We conclude that is also fundamental the support of family, as well as their presence in the school setting of students. When the student with disability has the support from their family and when the participate frequently in the subjects covered in school, we understand that this is a factor that helps in the fulfilment of the demands imposed in their everyday life. 
The inclusive education helps and contemplates the everyday life of people that need a differentiated attention. However, there is still the need for progress towards public policy besides investment in continuing education of pedagogical practice in order to promote an education that helps overcome difficulties and face challenges, so that those students can meet success.

\section{References}

[1] BELO, Chantal. CARIDADE, Helena. CABRAL, Luisa. SOUSA, Raquel, (2008). Deficiência Intelectual: Terminologia Conceptualização. Revistas Diversidades: Eixos de esperanças. V.22, Olinda: dezembro.

[2] BRASIL, (2019). Presidência da República. Casa Civil. Subchefia para assuntos jurídicos. Decreto $\mathrm{N}^{\circ} 3.298$ de 20 de dezembro de 1999. (1999). Regulamenta a Lei no 7.853 , de 24 de outubro de 1989. Dispõe sobre a Política Nacional para a Integração da Pessoa Portadora de Deficiência. Disponível em: http://www.planalto.gov. br/ccivil_03/decreto/d3298.htm. Acesso em: 05 mai. 2019.

[3] CARVAlHO, Rosita Elder, (2002). Removendo barreiras para a aprendizagem. 2. ed. Porto Alegre: Mediação.

[4] CERVO, Amado Luiz; BERVIAN, Pedro Alcino; SILVA, Roberto, (2007). Metodologia Científica.6. ed. São Paulo: Pearson Prentice Hall.

[5] COELHO, Cristina M. Madeira, (2012). Aprendizagem e Desenvolvimento de pessoas com deficiência. In: ORRÚ, Sílvia Ester: Estudantes com necessidades especiais: singularidades e desafios na prática pedagógica inclusiva.Rio de Janeiro: Wak Editora.

[6] CRESWELL, Jonh W., (2007). Projeto de Pesquisa: métodos qualitativos e misto. 2. ed. Porto Alegre: Artmed.

[7] DISTRITO FEDERAL, (2010). Secretaria de Estado de Educação. (SEEDF). Educação Especial: Orientação pedagógica. Brasília.

[8] GIL, Antonio Carlos, (2002). Como Elaborar Projetos de Pesquisa. 4. ed. São Paulo: Atlas.

[9] PARRA, Domingos Filho; ALMEIDA, João Santos, (2002). Metodologia Científica. 5. ed. São Paulo: Futura.

[10] ONU, (2019). Organização das Nações Unidas. CDPD - Convenção Internacional dos Direitos das Pessoas com Deficiência. Disponível em: https://www.fundacaodorina.org.br/a-fundacao/deficiencia-visual/convencao-da-onu-sobre-direitos-das-pessoascom-deficiencia/. Acesso: 17 de julho de 2019.

[11] SILVA, Carla Maciel da, (2016). Deficiência Intelectual no Brasil: uma análise relativa a um conceito e aos processos de escolarização. Dissertação de mestrado Universidade Federal do Rio Grande do Sul, Porto Alegre: UFRGS.

\section{Acknowledgements}

This work was supported by the University of Brasília (UnB) through the Research and Innovation Dean (DPI), the Support Coordination for People with Disabilities (PPNE) and the Scientific Initiation Program (ProIC). We also received support from the Federal District Research Support Foundation (FAPDF). 